\title{
PREVALENCE OF ANTIBODY TO HEPATITIS B VIRUS IN AN URBAN POPULATION OF NORTHEAST BRAZIL
}

\author{
L. G. LYRA (1), A. P. Damasceno (2), . P. COTRm (3), E. MOta (4) \& L. Silva (5)
}

\section{S U M M A R Y}

A sample of 1,288 inhabitants of Salvador, Bahia, Brazil, were submitted to the determination of anti-HBs using radioimmunoassay procedure, and analysed according to age, sex and income. Overall prevalence of anti-HBs was $11,8 \%$. ranging from $6,7 \%$ among children aged less than three years old to $26,1 \%$ among those aged 30 years and older. Males presented prevalence of anti-HBs similar to female individuals, and those with a higher income showed frequencies of anti-HBs greater than those with a lower income level. The following conclusions were drawn: The high prevalence of anti-HBs observed among children suggests early contact with hepatitis $B$ virus, possibly due to vertical transmission and intrafamiliar dissemination of the disease; the frequency of anti-HBs increases with age; the lower prevalence of anti-HBs among those with low income suggests that this group may present higher prevalence of carriers of the hepatitis $\mathrm{B}$ virus surface antigen.

KEY WORDS: Virus hepatitis B - Epidemiology - Antibodies - Northeast Brazil

\section{N T R O D U C T I O N}

The infection to hepatitis $B$ virus presents a worldwide distribution, although it is more prevalent in less developed countries of tropical and subtropical areas $1,3,4,11,14,20$ than in more developed countries 12,19 . Its relationship to the general socio-economic status of the population is better shown through the distribution of prevalence rates of hepatitis $\mathbf{B}$ virus markers according to the social classes within a country $15,17,18$.

The presence of antibody to the hepatitis $B$ virus surface antigen (anti-HBs) is indicative of past infection and represents acquired im. munity. Therefore, the epidemiologic value of determining the prevalence of anti-HBs is related to the understanding of transmission dynamics and the estimation of the susceptible population, aimed at planning controls programs.

Population-based studies describing the epidemiologic characteristics of the prevalence and distribution of anti-HBs in Brazil are lacking. This report describes the age and sex distribution of the prevalence of anti-HBs, accord-

This work was parttially supported by a grant from the Brazilian Research Council (Conselho Nacional de Pesquisa), project n..$^{\circ}$ 403489/81 and contracts n.os: 302239-83, 302229-83 and 302190-83, and was carried out at the Hepatology Unit of Hospital Professor Edgard Santos, Federal University of Bahia, Salvador, Brazil

. (1) Associate Professor. Department of Internal Medicine, Medical School, Federal University of Bahia

(2) Assistant Professor, Medical School, University of Piaui

(3) Assistant Professor, Department of Internal Medicine, Medical School, Federal University of Bahia

(4) Assistant Professor, Department of Preventive Medicine Medical School, Federal University of Bahia

(5) Assistant Professor, Department of Child and Maternal Health, Medical School, Federal University of Bahia

Correspondence to: Dr. Luiz G. Lyra - Hospital Prof. Edgard Santos - Rua João das Botas, s/n..$^{\circ}$ Canelas - 40000 Salvador - BA, Brasil 
LYRA, L. G.; DAMASCENO, A. P.; COTRIM, H. P.; MOTA, E. \& SILVA, I. - Prevalence of antibody to hepatitis B virus in an urban population of Northeast Brazil. Rev. Inst. Med. trop. São Paulo, 28:406-409, 1986.

ing to the socio-economic status of a defined population in Northeast Brazil.

\section{MATERIALS AND METHODS}

The study was carried out during 1981 and 1982 among residents of the city of Salvador. state of Bahia, an urban area of little over $1,500,000$ inhabitants. The study group comprised a sample of 1,345 individuals. Participants were selected randomly among children attending public and private schools and among adults seen at private and public physicians'offices and clinical laboratories throughout the city.

Blood samples were collected by venipuncture, and the sera obtained after centrifugation were stored at $-20^{\circ} \mathrm{C}$ freezer temperature. Determination of the presence of anti-HBs was performed by the radioimunoassay method, using standard procedure recomended for AUSAB reagents (ABBOT'T Laboratories).

Each serum sample was tested for transaminases before the determination of antiHBs and those individuals with elevated levels of transaminases ( $>50$ units, Reitman and Frankel method) were excluded from the study. This procedure was adopted in order to avoid the participation of individuals with potential liver disease, excluding from analysis some $\mathbf{5 7}$ sera samples. Further criteria for exclusion were the presence of jaundice or a diagnosis of liver disease at the moment of the clinical examination.

Information were collected from each participant on age, sex, educational level, occupation and income. On the basis of the total family income level, participants were divided into two groups: group I comprising those members of families with less than five persons and total family income equal to or more than US\$ 170 per month, and group II formed by those individuals with a total family income of less than US 170 per month.

\section{RESULTS}

The total of 1,288 individuals included in the study presented an overall prevalence of anti-HBs of $11,8 \%$. The proportion of those positive to anti-HBs increased from $6.7 \%$ for individuals aged less than three years, to a level of $26.1 \%$ for those aged more than 30 years (Table 1). The overall prevalence rate of anti-HBs was similar for males and females, respectively, $11.76 \%$ and $11.84 \%$. The age and sex distribution of positivity to and-HBs showed that females aged less than three years and 11 to 14 years old presented a rate higher than males of the same age groups, in contrast to a rate higher in males than in females for those aged seven to ten years, although these differences were not statistically significant.

T A B I E I

Age and sex distribution of prevalence rates of antibody to hepatitis $B$ surface antigen

\begin{tabular}{|c|c|c|c|c|c|c|}
\hline \multirow[b]{2}{*}{$\begin{array}{c}\text { Age } \\
\text { (years) }\end{array}$} & \multicolumn{2}{|c|}{ Males } & \multicolumn{2}{|c|}{ Females } & \multicolumn{2}{|c|}{ Total } \\
\hline & $\begin{array}{l}\text { Number } \\
\text { examined }\end{array}$ & $\begin{array}{c}\% \\
\text { positive }\end{array}$ & $\begin{array}{l}\text { Number } \\
\text { examined }\end{array}$ & $\begin{array}{c}\% \\
\text { positive }\end{array}$ & $\begin{array}{l}\text { Number } \\
\text { examined }\end{array}$ & $\begin{array}{c}\% \\
\text { positive }\end{array}$ \\
\hline $0 \ldots 3$ & 102 & 4.9 & 76 & 9.2 & 178 & 6.7 \\
\hline $4-6$ & 110 & 9.1 & 80 & 7.5 & 190 & 8.4 \\
\hline $7-10$ & 81 & 8.6 & 75 & 4.0 & 156 & 10.2 \\
\hline $11-14$ & 125 & 8.0 & 52 & 15.4 & 177 & 10.2 \\
\hline $15 \quad \ldots \quad 19$ & 110 & 12.7 & 97 & 12.4 & 207 & 12.6 \\
\hline $20-30$ & 87 & 12.6 & 132 & 12.9 & 219 & 12.8 \\
\hline$>30$ & 82 & 30.5 & 79 & 21.5 & 161 & 26.1 \\
\hline Total & 697 & 11.8 & 591 & 11.8 & 1288 & 11.8 \\
\hline
\end{tabular}

Individuals classified as part of group $I$, representing in this study a better socio-economic status, had an overall prevalence rate of anti-HBs of $13.9 \%$, in contrast to a rate of $9.4 \%$ observed for individuals in the group
II (Table 2), a difference that was statistically significant $\left(X^{2}=5.939\right.$, df $\left.=1, p<0.05\right)$. The prevalence rates of anti-HBs by sex were similar for males and females within each income level group. 
LYRA, L. G.; DAMASCENO, A. P.; COTRIM, H. P.; MOTA, E. \& SILVA. L. - Prevalence of antibody to hepatitis B virus in an urban population of Northeast Brazil. Rev. Inst. Med. trop. São Paulo, 28:406-409, 1986.

T A B I $\mathrm{E}$ II

Age distribution of prevalence rates of antibody to hepatitis $B$ surface antigen by income litve?

\begin{tabular}{|c|c|c|c|c|}
\hline \multirow[b]{3}{*}{$\begin{array}{c}\text { Age } \\
\text { (years) }\end{array}$} & \multicolumn{4}{|c|}{ Incoina ixisl } \\
\hline & \multicolumn{2}{|c|}{ Group I } & \multicolumn{2}{|c|}{ Group II } \\
\hline & $\begin{array}{l}\text { Number } \\
\text { examined }\end{array}$ & $\begin{array}{c}\% \\
\text { positive }\end{array}$ & $\begin{array}{l}\text { Number } \\
\text { examined }\end{array}$ & $\begin{array}{c}\% \\
\text { positive }\end{array}$ \\
\hline $0-3$ & 81 & 7.4 & 97 & 6.2 \\
\hline $4-6$ & 91 & 12.1 & 99 & 5.1 \\
\hline $7-10$ & 81 & 8.6 & 75 & 4.0 \\
\hline $11-14$ & 95 & 13.7 & 82 & 6.1 \\
\hline $15-19$ & 114 & 14.0 & 93 & 10.8 \\
\hline $20-30$ & 137 & 12.4 & 82 & 13.4 \\
\hline$>30$ & 91 & 28.6 & 70 & 22.9 \\
\hline Total & 690 & $13.9^{*}$ & 598 & $9.4^{*}$ \\
\hline
\end{tabular}

\section{DISGUSSION}

The overall prevalence rate of anti-FBs of $11.8 \%$ observed in Salvador is relatively low, however, this represents the frequency of antiHBs for a group of individuals of all ages. In fact, a study performed among blood donors in Brazil 6 observed prevalence of $26.7 \%$, a rate that is similar to that found in our study for individuals aged more than 30 years.

The gradual rise in the rate of positivity to anti-HBs by age is similar to that described in other populations 2,14. Moreover, the relati. vely high rates found among children in Salvador are comparable to those observed in areas where hepatitis $B$ virus in highly endemic ${ }^{7}$. This may reflect exposition to the virus in the first years of life, possibly due to vertical transmission 13,16 and intrafamiliar dissemination of the infection. In fact, the risk of acquiring the infection during the perinatal period may be as high as $40 \%$ to $50 \%$ in areas where hepatitis $B$ virus carriers are frequent $9,10,16$. This study showed that male and female individuals presented similar overall prevalence rates of anti-HBs. Serologic surveys carried out in different countries revealed that males presented a higher prevalence of hepatitis B surface antigen carrier state than females 14,18. However, other investigators have found a higher prevalence of anti-HBs among females than males ${ }^{15}$.

It was observed a lower rate of anti-HBs among those of a lower socio-economic level.
It is possible that the prevalence of hepatitis $\mathbf{B}$ virus carriers is higher in this group, decreasing the number of those presenting anti-HBs. In fact, this group are exposed to a higher risk of acquiring hepatitis $B$ virus earlier in life, with a consequently higher risk of developing the carrier state 7 . In addition, carriers of hepatitis B virus are more prone to develop liver disease including primary liver cancer or to develop antibody to hepatitis B only later in life 5,8 . Other studies are indicated to increase the knowledge on the epidemiology of the disease in Brazil.

\section{RESUMO}

Prevalência de anticorpos contra o vírus da hepatite $B$ em população urbana do nordeste brasileiro.

Um grupo de 1.288 individuos, residentes em Salvador, Bahia, Brasil, foi examinado para a determinação de anti-HBs, utilizando-se a técnica do radioimunoensaio. Os resultados foram analisados de acordo com a idade, o sexo e o nível de renda. Uma prevalência de antiHBs de $11,8 \%$ foi observada, variando de $6,7 \%$ nas crianças com idade inferior a três anos, a $26,1 \%$ para aqueles com idade superior a $\mathbf{3 0}$ anos. A prevalência de anti-HBs foi similar em individuos do sexo masculino e feminino. Aqueles com nível de renda mais alto tiveram prevalência de anti-HBs maior que o grupo de renda baixa. Dos resultados conclui-se: a alta prevalência de anti-HBs em crianças sugere o contato precoce com 0 virus da hepatite $B$, possivelmente relacionado com a transmissão vertical e a disseminação intrafamiliar do vírus; a frequiência de anti.HBs aumentou com a idade; a baixa prevalência de anti.HBs entre aqueles com baixo nível sócio-econômico sugere que neste grupo pode ser alta a prevalência de portadores do vírus $\mathbf{B}$ da hepatite.

\section{REFERENGES}

1. ANTONACIO, F. - Antigeno Austrália em duadores de sangue. São Paulo, 1971. (Tese do doutoramento Faculdade de Medicina da Universidade de São Paulo).

2. BARRETO, D. H.; BURKS, J. M.; MCMAHON, et al. - Epidemiology of hepatitis B in two Alaskan corn. munities. Amer. J. Epidem., 105: 118-122, 1977.

3. GOMES, L. S. C. - Estudo clínico $€$ histolígico de portadores assintométicos do antígeno de superfície da hepatite $B$ (AgHBs) e de seu anticorpo anti-HBs) eix. 
LYRA, L. G.; DAMASCeno, A. P.; COTRIM, H. P.; MOTA. E. \& SILVA, L. - Ptevalence of antibody to hepatitis B virus in an urban population of Northeast Brazil. Rev. Inst. Med. trop. São Paulo, 28:406-409, 1986.

Salvador, Bahia. Salvador, 1979. (Tese - Fuculdade de Medicna da Universidade Federal do Babia).

4. LYRA, L. G.; ANDRADE, Z. \& REBOUÇAS, G. Hepatitis B surface antigen "Carrier State" in hepatosplenic schistosomiasis. Gastroenterology, 71: 641, 1975.

5. MAUPAS, P.; LAROUZE, B.; LONDON, W. T. et al. - Antibody to hepatitis $B$ core antigen in patients with primary hepatic carcinoma. Lancet, 2: 9-11, 1975.

6. MAZZUR, S.; NATH, N.; FANG, C. et al. - Distribuicion de marcadores de virus de hepatitis $\mathbf{B}$ (VHB) en la sangre de donadores de 13 paises del hemisferio occidental. Actas Del Taller Latinoamericano de Cruz Roja sobre Hepatitis B. Bol. Otic. sanit. panamer., 89: 239-248, 1980.

7. MAZZUR, S. \& JONES, N. - Distribution and persistence of hepatitis B surface antigen and antibody in a Melanesian population. Amer. J. Epidem., 105: 107-112, 1977.

8. OHBAYASHI, A.; OKOCHY, K. \& MAYUMMI, M. Familial claustering of asymptomatic carriers of Australia antigen in patients with chronic liver disease or primary liver cancer. Gastroenterology, 62: 618-625, 1972 .

9. OKADA, K. e al. - Hepatitis B surface antigen in the serum of infants after delivery from symptomatic carrier mothers. J. Pedlat., 80: 360, 1975.

10. PAPAEVANGELOU, G.; HOOFNAGLE, J. H. \& KREMASTINOU, J. - Transplacental transmisston of hepatitis $B$ virus by symptom-free chronic carrier mo* thers. Lancet, 2: 746-748, 1974.

11. PRINCE, A. M. - Prevalence of serum hepatitis antigen (SH) in different geographic regions. Amer. $J$. trop. Med. Hyg., 19: 872-879, 1970.
12. SCOTT, R.; SCHNEIDER, R. J.; SNITBHAN, R. et al. - Factors relating to transmission of viral hepatitis in a United States Military Population Stationed in Thailand. Amer. J. Epidem., 113: 520-527, 1981.

13. SCHWEITZER, I. L.; MOSLEY, J. W.; ASHCAVAI, $M$. et al. - Factors influencing neonatal infection by hepatitis B virus. Gastroenterology, 65; 277-283, 1973.

14. SOBESLAVSKY, O. - Pravalence of markers of hepatitis $\mathbf{B}$ virus infection in varlous countries: a WHO colleborative study, Bull. Whd. Hth. Org., 58: 621628,1980 .

15. SKIHOI, P. - Hepatitis and hepatitis $\mathbf{B}-$ antigen in Greenland. Ir - Occurrence and interrelation of hepatitis B associated surface, core and antigen antibody system in a highly endemic area. Amer. $J$. Epidem., 105; 99-106, 1977.

16. STEVENS, C. E.; BEASTEY, R. P.; TSUI, J. \& LEE, W. - Vertical transmission of hepatitis $B$ antigen in Taiwan. New Engl. J. Med., 292: 771-775, 1975.

17. SZMUNESS, W.; DIENSTAG, J. I.; PURCELL, R. H. - Distribution of antibody to hepatitis A ant1gen in urban adult populations. New Engl, J. Med., 295: $755-759$, 1976 .

18. SZMUNESS, w. - Recent advances in the study or the epldemiology of hepatitis B. Amer. J. Path., $629.650,1975$.

19. VILLAREJOS, V. M.; PROVOST, P. J.; 1TTENSOHN, O. L. et al. - Seroepidemiologic investigations of human hepatitis caused by $A, B$, and possibie third virus. Proc. Soc. exper. Blol. (N.Y.), 152: 525.528, 1976.

20. VYAS, G. N. \& SHULMAN, N. R. - Henagglutination assay for antigen and antibody associated with virul hepatitis. Science, 170: 332-333, 1970.

Recebido para publicação em 25/11/1985. 